\title{
Reinforcers and Inhibitors of Family-based Stunting Children Parenting (Case Studies in Slums Area of Makassar City)
}

\author{
Rizky Chaeraty Syam ${ }^{1}$, Muhammad Syafar ${ }^{1 \star}$, M. Alimin Maidin², Muhammad Rachmat ${ }^{1}$, Uyuun Wiji Ismita ${ }^{3}$, Iva Hardi Yanti ${ }^{4}$, \\ Erniwati lbrahim ${ }^{3}$ \\ ${ }^{1}$ Department of Health Promotion and Behavioral Sciences, Faculty of Public Health, Hasanuddin University, Makassar, \\ Indonesia; ' 2 Department of Hospital Management, Faculty of Public Health, Hasanuddin University, Makassar, Indonesia; \\ ${ }^{3}$ Department of Environmental Health, Faculty of Public Health, Hasanuddin University, Makassar, Indonesia; ${ }^{4}$ Department of \\ Epidemiology, Faculty of Public Health, Hasanuddin University, Makassar, Indonesia
}

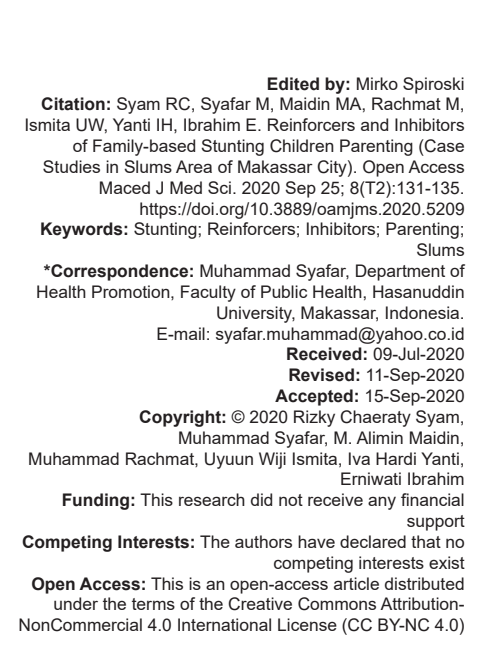

\section{Abstract}

BACKGROUND: Stunting is a condition of failure to thrive in toddlers (5-year-old babies) with length or height of the body under minus two standard deviations (<-2SD). This is caused by chronic malnutrition and recurrent infections, especially in the first 1000 days of life.

AIM: This study aimed to examine the parenting style of family-based stunting children seen from the reinforcers and inhibitors of stunting in Makassar City Slums.

METHODS: This type of research is qualitative research with a case study approach. Informants, in this study, were 26 people, consisting of families with stunting children aged 0-59 months in 2019 as many as 14 people, families who have stunting children aged 0-59 months in 2018 and are free from stunting as many as four people, one nutritionist, four Integrated Healthcare Center cadres, and three Community Leaders/Religious Leaders. Analysis of the data used is content analysis which is then interpreted and presented in the form of narratives, matrices, and schemes.

RESULTS: The reinforcers factors consisting of adequate health service support and family members provide support in caring for children and providing nutritious food. While the inhibiting factors consist of uncertain family income for the daily needs of family members, and irregular nutritional food intake is given in a day. The need for nutrition education for community stunting management was analysed by the public health center and integrated health-care center through a program to improve the first 1000 days of life and increase family planning coverage.

CONCLUSION: Based on the results of research and discussion of the reinforcers factor of family-based stunting children parenting in the slums of Makassar City. Hence, it can be concluded that the reinforcers factor consists of support for health services that are already quite good, and family members provide support in child care. While the inhibitors factors consist of uncertain family income for the daily needs of family members, and irregular nutritiona food intake is given in a day.

\section{Introduction}

Stunting is a condition of failure to thrive in toddlers (5-year-old babies) with a length or height of the body under minus two standard deviations (<-2SD). This is caused by chronic malnutrition and recurrent infections, especially in the first 1000 days of life. Thus, the child's height is shorter and very short compared to normal children his age and has a delay in thinking [1], [2].

Parenting is an important role for growth disorders in children. There are three components that must be considered, namely, food, health, and psychosocial stimulation are factors that play a role in optimal child growth [3], [4]. Parenting is an interaction between parents and children consisting of caring practices and the practice of providing food to children [5]. There is a relationship between parenting parents in terms of caring attitude and practice of feeding toddlers with the nutritional status of toddlers (weight/age) [6]. The better parenting provided, the better the nutritional status of toddlers and vice versa if the mother provides poor parenting in providing food to toddlers, the nutritional status of toddlers will also be disrupted [7].

Nutrition Status Monitoring in 2016 in Makassar City prevalence of stunting was $25.2 \%$, while the 2018 data prevalence of stunting $5.04 \%$ and increased again in June 2019 by $2.97 \%$ [8]. The previous research conducted in Tallo District showed that the number of stunting children aged 18-23 months was 39.3\%. Where there is a significant relationship between the attention/support of mothers to children in the practice of feeding, psychosocial stimulation, hygiene/hygiene, and environmental sanitation as well as the utilization of health services with the occurrence of stunting. Based on Sakti [9] conducted in Slum City of Makassar, based on primary data from the Rappokalling Community 
Health Center, the number of stunting children aged 24-59 months was $25.4 \%$ and the results showed a relationship between LBW risk, breastfeeding which is not exclusive, a history of infectious diseases, maternal education, and low income are risk factors for stunting. Nutritional care is also a pattern of behavior in the practice of providing care performed by parents, grandparents, grandmothers, caregivers, nurses or even neighbors, and siblings who are related to nutritional status. There are three factors that influence nutrition parenting, namely, sociocultural, and political and economic conditions [10].

Based on some of the facts that have been described in the previous paragraphs, it can be seen that although there has been a lot of research related to the determinants and patterns of handling stunting in Indonesia, particularly in the aspect of giving care. However, there is still little research related to aspects of reinforcers and inhibiting family-based parenting. This study examines the reinforcers and inhibitors aspects of the adoption of family-based stunting parenting in the Slums of Makassar City.

\section{Materials and Methods}

This research was conducted in the Slums of Makassar City in four villages, namely, Rappokalling, Tammua, Buloa, and Tallo which are the working areas of the Rappokalling Health Center. The research approach used in this research is a case study approach with qualitative research type.

There are 26 informants in this study, consisting of the main informants divided into two families " $A$ " (families who have stunting children aged 0-59 months in 2019 and are still stunted) 14 people and families "B" (families who have stunting children) age 0-59 months in 2018 and free from stunting) four people, supporting informants, namely, one Nutrition Officer, four Integrated Healthcare Center Cadres, and three Community Leaders/Religious Leaders. The age of the informants interviewed in-depth interviews ranged from 21 to 61 years.

Primary data were collected through observation to obtain information about the general picture of parenting reinforcers and inhibitors of familybased stunting children, interviews with in-depth interviews (in-depth interviews) conducted on key informants and supporting informants, based on interview guidelines that have been prepared.

The analysis of the data used in this study is content analysis which is then interpreted and presented in the form of narratives and matrices. Content analysis is used to draw conclusions through attempts to find the characteristics of the message and is carried out objectively and systematically.

\section{Results}

\section{Reinforcers factors}

Reinforcers factors health education for familybased stunting child care in the slums of Makassar City consists of support for health services, and family support. The following are excerpts from interviews with informants about the reinforcers factors.

"...lya adaji kaya apa itue suntikan anu' tambahan Rubella dengan vitaminto diinformasikan Eh, sebentar pembagian vitamin kesana ke Posyandu datang meki..." (SS, 41 Tahun)

“...lyaa...sendiriki dengan 30 Posyandu dededeee...Dibantumi sama anu kedong temanteman lintas program dibantu sama kader, kader aktifji bagaimana tidak aktif ada insentifnya ada absennya juga suka rela sebenarnya cuma dikasi insentif..."(EV, 42 Tahun-Petugas Gizi)

“...Dekatji kalo yang disini di belakang kantor lurah tapi kalo yang disana iyya jauhki kalo mauki periksa disitu baru biasa dirujukki kesana kalo nda bisa disini. Di pustu masih kurang dokter dan alatnya jadi pasti selalu dikasi rujukan ke Rappokalling..." (RT, 38 Tahun)

From interviews with informants it is known that the type of information provided by health workers is, provision of vitamins and additional injections of Rubella, information about non-communicable diseases, pregnancy problems, infants and toddlers, and environmental health through counseling. Related to the availability of health human resources; in this case, Nutritionists are known to be overwhelmed to be active directly in 30 Integrated Healthcare Center in their working area. With the Integrated Healthcare Center cadre and cross-program cooperation we can help the implementation of nutrition programs in the region. The availability of health facilities, some informants complained about the distance to the public health center but there were already integrated healthcare center and auxiliary health center which had a short distance from the community's residence and could be accessed only on foot.

The results of interviews with informants regarding family support can be seen from the following quote.

"...Didukungja semua itu sama keluargaku karna itu anu bagusji memang semua...” (ML, 31 Tahun)

“...Baa, tapi sayaji nda mendengar Heheheee biasa malas iyeee, ehh anu bikin bubur iyee yahh biasa buryam atau bur SUN ya itu saya kasi kalo orang tuaku nasarangkangnga biking iyyya tapi dehhh biasa kalo nda anui basimi malaskito namakan baru gelek-gelek kalo saya makangngi Heheheee..." (RO, 21 Tahun)

“...Jarangji bu dia ka kerjai paling anakkuji saja bantu-bantuka...” (NA, 41 Tahun) 
“...iyaa...biasa kalo anu makanki bapaknya pii disitu mau makan juga makam nasi apa, biasa juga kalo naliatki kakaknya minum-minum es nangiski juga kalo nda dikasi heheheee..." (RT, 38 Tahun)

From interviews with informants, it is known that family support in child care provision in the form of exclusive breastfeeding, age of complementary feeding, and immunization get full support from family members, but sometimes parents who do not pay attention to providing nutritious food for their children. Environmental cleanliness is more dominantly done by the informants themselves, other families only help if they are on holiday and are at home. Provision of food intake what they eat to children if they want it because if not given the child will cry.

\section{Inhibitors factors}

The inhibiting factors of family-based stunting health education for family-based stunting in the slums of Makassar City consist of family income, and food intake. The following are excerpts from interviews with informants about the inhibiting factors.

“...Eee... anakku tiga, lima'ka Heheheee. Anuu... Ya'bo-ya'bokki Heehehee. Biasa ta' dua hari pi baru ditimbang biasa ta'100 biasa juga lebi kadang juga nda cukuki 100 Hehehee..." (KM, 31 Tahun)

“...Nda kerjaka mauka kerja bagaimana pernaja itu waktu bulang anu pigika mengulun tapi nda mi skarang karna jaga anak-anak baru masi skola semua yang dua kakanya ini..." (KM, 31 Tahun)

“...Baku gabungji. lyaa, makan belanja. Biasa per pekan, biasa itu sampe 7 liter iyaa delapan. Eh, sekitar empat puluh ribu biasa ikan sayur eh kadang ikut tempe, tahu iyya itu telur karna anak-anak nda suka makan ikan. Kalo jajan iyya nda banyakji paling Rp. 5,000 ji..." (SS, 41 Tahun)

We analyzed data from the interviews related to family income chosen from the number of family members ranging from 3 to 8 people in one household. Most of the fixed income is obtained from husbands who work as day laborers. Most of the informants have additional income and there are some informants who do not have additional income except from fixed income. Allocation of daily expenses for childcare and research informant feeding where the costs incurred per day for daily food needs from morning to night starting from Rp. 30,000 to Rp. 50,000 .

The results of interviews with informants regarding food intake can be seen from the following quote.

“...Inee...malaskieee biasa satu hari satu kaliji makan nasi, telur biasa makanang anuji ringanji biasa banyak namakang...” (TN, 21 Tahun)

"...Tiga kali sehari, itupun kalo anuii mintaki nasi. Anujii... biasa nasi air sayur jiii... kalo tidak ada mintai telur hehehee kalo ikan kadang-kadang'ngi makan ikan. Makan ji nasi tapi, ta'sedikitji. Kurngngi jajanna dia..." (MN, 34 Tahun)

“...Nda ada mau tongpi, ASI iyya atau makanan cemilan itu jajan-jajan kenyangmi anu gorengan yang kriuk itu jarangji gula-gula, teh Eco naminum juga terus..." (RO, 21 Tahun)

From the results of interviews related to the habit of giving meals in a day starting from 1 to 3 times a day there are even children who sometimes do not eat at all in a day the child wants more frequent snacks than eating. Foods given to children such as rice, side dishes, and vegetables even though the child's appetite are small. Providing food given to children if they are lazy to eat and more often snacks, which are to persuade children slowly to want to eat, do not force the child because if he is forced he will cry and spit out his food, give milk or formula milk.

\section{Discussion}

The results of this study indicate that the reinforcers and inhibitors factors related to familybased stunting parenting in the Slums of Makassar have several aspects. The following is a discussion of the results of the study.

The reinforcers factor for stunting parenting consists of support of health services seen from access to information where the provision of information to the public has been done by Health HR and the way of providing information is quite good because in general informants can obtain information with good health education Integrated Healthcare Center and at the health center. lack of availability of Health HR (Nutritionist) in conducting health interventions to the community where there is only one Nutritionist to handle 30 integrated healthcare center in four Kelurahan. However, crosssectorial cooperation can be established and also empowering integrated healthcare center cadres to conduct health interventions directly to the community.

Mother of children under five who get guidance from cadres will participate well to integrated healthcare center, because there is a sense of recognition and attention given by integrated healthcare center managers so that mothers of toddlers routinely come to integrated healthcare center [11]. Research conducted by Welasasih et al. [12] shows that attendance at integrated healthcare center is an indicator of the reach of basic health services for integrated healthcare center including monitoring of growth and growth.

In addition, research conducted by Maharsi [13] shows that knowledge of cadres is one of the keys in the service system at Posyandu, because with cadres who will get a positive response from mothers who have 
children under five, it is easy to be adjusted friendly and well organized services. This encourages toddlers to visit the posyandu diligently.

The results showed that the informants received full support from family members who live in the same house; although there was still a perception that immunization could cause side effects such as paralysis. As for the pattern of child care seen from the provision of food intake, other family members have not provided significant support because it still prioritizes what the child wants rather than paying attention to the nutritional content of the food to be provided.

This study is in line with what was done by Yudianti and Saeni [14], which shows a relationship between feeding practices and personal hygiene to stunting, while the practice of personal hygiene related to the incidence of stunting. Other studies that are in line with this study were also conducted by Waroh [15] on toddlers who experience poor nutrition, family support is very important to pay attention to adequate and balanced nutrient density so that the physiological and immunological body of a toddler can return to normal and can increase body weight. Stewart [16] stated that nutrient deficiency or excess in the 0-2 years ago period will generally have an impact on the quality of life of children. Nutritional deficiencies in children under five will eventually cause stunting so that it disrupts the growth and development of infants, while excess nutrition causes obesity.

Family income in residential areas where the majority of community employment is laborers with varying income levels earned per day, per week, or per month. The economic level of most residential communities is at the lower middle level with the largest number of family members of more than seven people in one household. The results showed that most residential communities have additional income in the household. Allocation of daily expenses for childcare and feeding per day ranges from Rp. 30,000 to $\mathrm{Rp}$. 50,000 which is used for the cost of meals per day as a family from morning to night. The community prefers to spend more on snacks than the cost to meet family nutrition intake.

The study conducted by Illahi [17] showed the results of statistical tests that there was a relationship between family income, birth weight of children under five, and length of birth of children under five with stunting in Ujung Piring Village, Bangkalan. Income factor becomes the dominant factor in the occurrence of stunting. A parallel study was conducted by Ngaisyah [18] which showed that in the stunting group, the income was below the UMR of 67 respondents (35.8\%), while those who had an income above the UMR were only 45 people (22\%).

The results of this study indicate that the way of giving food to children in a day mostly only feed children as much as 1-3 times with food intake that lacks good nutrition for children. Parents sometimes prefer to follow the desire to eat their children who prefer to eat snacks and drink milk instead of eating rice, side dishes, and food. Fulfillment of adequate nutrition, both macronutrition and micronutrition are needed to avoid or reduce the risk of stunting [19].

Another parallel study was also conducted by Welasasih and Wirjatmadi [12] which showed a significant relationship between the types of consumption of children under five with the nutritional status of stunting children in the village of Kembangan with $p=0.035$ ( $p<0.05)$. The types of food consumed in the stunting toddlers group are mostly with a menu composition consisting of staple foods + side dishes + vegetables which is an incomplete daily menu. The type of food consumption greatly determines the nutritional status of a child, said that the food is of good quality if the daily menu provides a nutritious, balanced, and varied menu according to his needs [19], [20], [21].

Eating habit is a human behavior toward a food such as attitude, belief, and selection in consuming food that is obtained repeatedly. Children's nutritional condition is influenced by various factors, which are divided into direct and indirect causes. The immediate cause is the adequacy of food and the state of children's health. Indirect causes are family food security, care for mothers and children, and environmental sanitation [4].

\section{Recommendation}

It is hoped that the Regional Government of Sidenreng Rappang Regency will be more strict in applying sanctions for violators of the marriage law in accordance with applicable regulations, and parents or families should equip their children with education to a higher level so that they develop critical thinking patterns and rational, especially in preparing for their marriage.

\section{Conclusion}

Based on the results of research and discussion of the reinforcers factor of family-based stunting children parenting in the slums of Makassar City. Hence, it can be concluded that the reinforcers factor consists of support for health services that are already quite good, and family members provide support in child care. While the inhibitors factors consist of uncertain family income for the daily needs of family members, and irregular nutritional food intake is given in a day.

\section{References}

1. Hagos S, Hailemariam D, Wolde-Hanna T, Lindtjorn B. Spatia heterogeneity and risk factors for stunting among children under age five in Ethiopia: A Bayesian geo-statistical model. 
PLoS One. 2017;12(2):1-11. https://doi.org/10.1371/journal. pone. 0170785

2. Kemenkes RI. Buletin Jendela Data dan Informasi Kesehatan: Situasi Balita Pendek (Stunting) di Indonesia. Jakarta: Kementerian Kesehatan Republik Indonesia; 2018.

3. Engle PL, Menon P, Haddad L. Care and nutrition: Concepts and measurement. World Dev. 1999;27(8):1309-37. https://doi. org/10.1016/s0305-750x(99)00059-5

4. Pratiwi TD, Masrul M, Yerizel E. Hubungan pola asuh ibu dengan status gizi balita di wilayah kerja puskesmas belimbing kota padang. J Kesehatan Andal. 2016;5(3):661-5. https://doi. org/10.25077/jka.v5i3.595

5. Ratu VN, Malonda NS, Punuh MI. Hubungan antara pola asuh dengan status gizi pada anak usia 24-59 bulan di wilayah kerja puskesmas pusomaen kabupaten minahasa tenggara. Kesmas. 2019;7(3):1-8. https://doi.org/10.35799/jbl.9.1.2019.23421

6. Kuhu A, Punnuh MI, Kapantow NH. Hubungan antara pola asuh ibu dengan status gizi balita di wilayah kerja puskesmas kakas. Med Kesehatan. 2016;8(3):1-9. https://doi.org/10.25077/jka. v5i3.595

7. Munawaroh S. Pola asuh mempengaruhi status gizi balita relationship of parenting pattern and toddlers nutrititional status. J Keperawatan. 2016;6(1):44-50.

8. Dinkes Kota Makassar. Data Kejadian Stunting Di Kota Makassar. Makassar: Dinas Kesehatan Kota Makassar; 2019. https://doi.org/10.32382/medkes.v11i2.236

9. Sakti UH, Ansariadi, Sirajuddin S. Risk factors of stunting case on children aged 24-59 months in slums of Makassar city. IOSR J Nurs Health Sci. 2018;7(3):17-22.

10. Barahima JJ, Noor NN, Jafar N. Relationship of economic and social culture status in the first 1000 days of life (HPK) period toward events of stunting in children ages of 0-24 months in Barebbo district working area, bone regency. East Afr Sch Publ. 2019;1(4):206-11. https://doi.org/10.1016/j.enfcli.2019.10.091

11. Sambas G. Faktor-Faktor Yang Berhubungan Dengan Kunjungan Ibu-lbu Anak Balita ke Posyandu di Kelurahan Bojongherang Kabupaten Cianjur, Tesis. Depok: Fakultas Kesehatan Masyarakat Universitas Indonesia; 2014. https://doi. org/10.33757/jik.v2i1.62

12. Welasasih BD, Wirjatmadi RB. Beberapa faktor yang berhubungan dengan status gizi balita stunting. Public Health. 2012;8(3):99-104.

13. Maharsi R. Faktor-Faktor Yang Mempengaruhi Kepatuhan Ibu Balita Datang ke Posyandu di Wilayah Kecamatan Bekasi Utara Kota Bekasi Tahun 2007, Tesis. Depok: Fakultas Kesehatan Masyarakat Universitas Indonesia; 2016. https://doi. org/10.33757/jik.v2i1.62

14. Yudianti Y, Saeni RH. Pola asuh dengan kejadian stunting pada balita di kabupaten polewali Mandar. J Kesehatan Manarang. 2017;2(1):21-5. https://doi.org/10.33490/jkm.v2i1.9

15. Waroh YK. Pemberian makanan tambahan sebagai upaya penanganan stunting pada balita di Indonesia. Embrio. 2019;11(1):47-54. https://doi.org/10.36456/embrio.vol11.no1. a1852

16. Stewart CP, lannotti L, Dewey KG, Michaelsen KF, Onyango AW. Contextualising complementary feeding in a broader framework for stunting prevention. Matern Child Nutr. 2013;9(2):27-45. https://doi.org/10.1111/mcn.12088 PMid:24074316

17. Illahi RK. Hubungan pendapatan keluarga, berat lahir, dan panjang lahir dengan kejadian stunting balita 24-59 bulan di Bangkalan. J Manajemen Kesehatan Yayasan. 2017;3(1):1-7. https://doi.org/10.29241/jmk.v3i1.85

18. Ngaisyah RD. Hubungan sosial ekonomi dengan kejadian stunting pada balita di desa kanigoro, Saptosari, Gunung Kidul. Med Res. 2015;10(4):65-70. https://doi.org/10.35842/ mr.v14i1.212

19. Muhith A, Winarti E, Perdana SS, Haryuni S, Rahayu KI, Mallongi A. Internal locus of control as a driving factor of early detaction behavior of servical cancer by inspection visual of acetic acid method. Open Access Maced J Med Sci. 2020;8(E):113-6. https://doi.org/10.3889/oamjms.2020.4341

20. Mallongi A, Birawida AB, Astuti RD, Saleh M. Effect of lead and cadmium to blood pressure on communities along coastal areas of Makassar, Indonesia. Enferm Clín. 2020;30(4):313-7. https:// doi.org/10.1016/j.enfcli.2020.03.001

21. Mitra M. Permasalahan anak pendek (stunting) dan intervensi untuk mencegah terjadinya stunting (suatu kajian kepustakaan). J Kesehatan Komunitas. 2015;2(6):254-61. https://doi. org/10.25311/jkk.vol2.iss 6.85 